\title{
URBAN PLANNING OF THE SOUTHEAST PART OF TRAPEZITSA IN THE LIGHT OF THE LATEST RESEARCH
}

\author{
Mirko Robov \\ National Archaeological Institute with Museum at \\ Bulgarian Academy of Sciences, Veliko Tarnovo, Bulgaria \\ mrobov@abv.bg
}

\begin{abstract}
After the 30's of the 13th century and until the end of the Tarnovo Kingdom in the south-east sector of Trapezitsa a specific urban planning was taking shape. Over several ledges are built some of the most significant Metropolitan churches, such as church № 3, 4 and 14, as well as a large closed ensemble near church №3, related to an eminent representative of the ecclesiastical hierarchy - most likely the bishop of this second in significance Metropolitan fort. Immediately south of the episcopate is attached a large duplex building, with an imposing appearance - columns and an arch construction. From the east it ends with an apse. There are no traces of mural paintings on the plastered walls. Among the findings there is a vessel with an image of the Star of David.

It is possible that this building had social and religious functions and was related to the Jewish people, who inhabited this fort during the 13th-14th centuries of Metropolitan Tarnovo.

Jewish People

Keywords: Trapezitsa; Church; Episcopate; Complex;
\end{abstract}

\section{ГРААОУСТРОЙСТВОТО В ЮГОИЗТОЧНАТА ЧАСТ НА ТРАПЕЗИЦА В СВЕТАИНАТА НА НОВИТЕ ПРОУЧВАНИЯ}

\author{
Мирко Робов
}

Национален археологически институт с музей при

Българска акалемия на науките, Велико Търново, България

\begin{abstract}
Pезюме: СлеА 30-те години на 13 век и Ао края на Търновското царство в югоизточния сектор на Трапезица се офрормя градоустройствена картина на тераси са издигнати някой от найзначимите столични цьркви - с номера 3, 4 и 14, както и голям затворен ансамбъ^ при цьрква №3 свързан с вилен прелставител на църковната йерархия/най-вероятно епископьт на тази втора по значимост столична крепост/. Непосредствено южно АО епископията е Аолепена голяма $в$ велна постройка, офрормена представително - колони и аркова конструкция. От изток е завършвала с апсиАа. По измазаните с хоросан стени няма останки от стенопис. СреА откритите нахолки е съА с изобразена звезла на АавиА. Напьлно възможно е тази сграда $а$ а е била натоварена с
\end{abstract}


обществени и религиозни функции и да е свързана с обетавалите тази крепост евреи през столично Търново - 13-14 век. евреи

КАючови Ауми: Трапезица; цьрква; епископия; комплекс;

На 18 март 1879 г. се учредява пьрвото в страната археологическо Аружество - Търновското (Domuschiev, 1967, р. 61). Основен момент в програмните му цели е провежлането на археологичеки разкопки на трапезица. Те започват още същата голина (Beron, 2004, р. 18). Сьсредоточени са в северната част на билото и са под ръководството на А-р Васил Берон и профр. Марин Аринов.

Последват разкопки през 1884 г. Сьсредоточени са в Югоизточния сектор на крепостта като обхващат цьркви с номера 3 и 4. Това е всъщност пьрвият етап на проучването на въпросните култови паметници, тъй като повторно тук се работи и през 1900 г. поА рьководството на фрранския археолог Жорж Сьор (Nikolova, 1962, р. 35). В миниатюрата върху ^ист №2 от Ватиканкия препис на Манасиевата хроника (Duychev, 1962, р. 32), сектора е отразен с крепостната стена и няколко цьркви. ВиАимо от архитектурните особености, еАната от цьрквите е куполна, а Аруги Аве са с Авускатни покриви и еАноскатно покритие на странични галерии. Цвета на покривните материали показва, че куполната цьрква е покрита с оловни листове. При останалите цьркви са използувани керемили.

Църква №3 е с частично запазени гралежи и много малки пасажи от вътрешната цокъ^на стенопис. В плана й са поставени Ава вхола съответно в запалния зил на притвора и в южния зил на наоса. От север е ситуирано помещение, прилепено към цьрквата. Четири правоъгьлни фундамента с посока север-юг, разположени запално от храма. Външният зил на помещението от север продьлжава към запал, като огражАа широко Аворно пространство. Оформени са пиластри откъм южното му мице. Както пише Н. Мавродинов, планът на Васи^ Аимов (Dimov, 1915) е неточен, но $А$ ава важни архитектурни подробности за

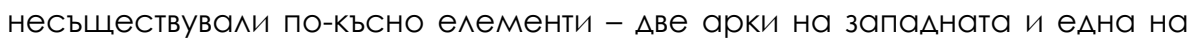
южната фрасала на цьрквата (Mavrodinov, 1931, р. 36). Цьрквата е била повторно разкопана от Жорж Сьор през 1900 гоА., като Аанните от това 
проучване не са известни. По план цьрквата е еннокорабна, крьстокуполна, с еАин притвор.

Общите й размери са 13/8 м. Апсидата е полукрьгла. Суперструкцията е запазена на максимална височина от 0,60 м. Гралежът на източната фасала е положен върху солилен блокаж, залят обилнос хоросанов разтвор.Този конструктивен похват е приложен с це^ належАното укрепване на терена, тъй като източният зиА на цьрквата попала в самия край на терасата, а от там, към източната крепостна тена на Трапезица, тереньт е със силно изразена Аенивилация. Това именно е наложило неговото Аопьлнително укрепване. В офрормлението

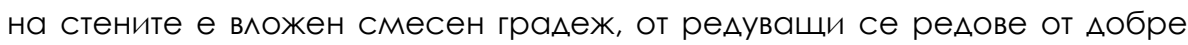
обработени камъни, с грижливо оформени Аица,които се редуват с тухлени редове. Затова свилетелстват многобройните екземпляри от цели и фррагметирани тухли в насипа около цьрквата, а също и от отлелни пасажи от градежа във вътрешността на цьрквата. Наосът е с форма на квалрат. Прелолтарното пространство е разделено на три части от Аве стени, оформени с арки. Самият олтар е по-широк от наоса, като „напомня крьстовидните източни цьркви в форма на буквата T" (Mavrodinov, n.d., p. 36). Пространството е отлелено с Аве колони, като базите им са стьпвали на зиАани фрунАаменти, правоъгьлни по фрорма.

Били са разположени симетрично върху Авата стилобата, които опират в края на олтарната ниша. Запазен кьм времето на новите проучвания, е само северният от тези орундаменти. Носещите елементи на полКуполният барабан от запал са Ава масивни зилани пиластри с внушителни размери.

Ао запазената височина на фасалните стени са стьпвали вьрху сравнително висок цокъ^. Керамопластични елементи /кръгли панички и четирилистници/ са обогатявали декоративно-художествения образ на фрасалните стени, изгралени грижливо, с техниката на смесения гралеж. Това представя цьрква №3 като един типичен представител на Търновската архитектурна школа с живописно-Аекоративните похвати, които познаваме от Аруги проучени паметници на Царевец и по Авата бряга на янтра (Robov, 2002a, p. 251), (Robov, 2002b). Протезисната /в покъСно преустройство зазиАана/ И Аиакониконна ниши започват ниско, малко наА нивото на пола. Южният вхол е в запалната половина на 
южния зил на наоса. Съорьжението отвежла към южната странична галерия на цьрквата.

Подовото покритие на цьрквата пьрвоначално е изпьлнено с тънки п^очи от сИв камък, положени върху хоросанова поА^ожка. По-късно е положена втора, тухлена полова настилка, също върху хоросанова замазка. От вътрешната стенопис in situ ca запазени малки пасажи от цокъ^ната живопис, вьрху северната стена и в олтарната ниша. Те са от цокьАната живопис на наоса.

ПреАимно от цокъАната стенопис са и многобройните Аребни фрагменти, открити при разчистването на гробничните съорьжения в притвора, а също и в насипните пластове около цьрквата. В притвора са установени Аве гробни съорьжения - съответно в северната и южната му части. Гробниците са зилани, като северната е грижливо измазана. Тъй като скелетите не са запазени, очевидно и Авете гробници са били отваряни, но неизвестно кога - по време на робството или при разкопките на В.Берон и Ж.Сьор. Ава оррагмента от мраморни налгробни плочи, за съжаление без орнаменти и налписи, свиАетелстват за ранга на погребаните тук високопоставени хсветски или Ауховни персони. ЕАновременно и еАнотипно са оорормени страничните галериите на цьрквата. Те са от запал и юг. Масивните Аьрвени колони, които са носели еАноскатния покрив са стьпвали на пет правоъгълни зилани фундамента. При южната галерия тази функция е отредена на пет уширения в стилобатния зиА, които пьрвоначално са били отАелни правоъгъАни фрундаменти, но по-късно пространството межАу тях е било запьлнено с гралеж. ЕАнотипна е и плочниковата настилка в очертанията на запалната и южната галерии. Тази настилка продьлжава запално и югозапално, извън очертанията на цьрквата. Интересен момент, найвероятно с отношение към храмовия патрон на цьрква №3, е и група от полглазурни монограми вьрху сьлове, изработени в сграфито техника, с буквата „Б". УспореАно с тях, се откриват и вторични издрасквания на същата буква върху обратните страни на дъна и стени на керамични сьдове от сьщия периол.

Самото явление, най-общо свързано с култа към царя, патриарха, към патрони на важни столични храмове и др. (Robov, 1999, p. 521), се 
отнася към средата и втората половина на 14 век в материалната и Ауховната култура на столично Търново.

Отмира с палането на грала, катко образци от слелващи периоли не са установени (Robov, 1999, рр. 521-522). Вьпросната група от комп^екса при цьрква №3 е от наА Авадесет монограма, като еАинични находки са известни и от проучванията на манастира „Св. Иван Ри^ски", в югозапалния сектор на Трапезица. Тук само ще отбележим, като пример, че най-голямата група подглазурни монограми с буквата „М" /40/ се откриват именно в манастира „Св. Четиридесет мъченици”, в т.нар. Нов грал и имат непосредствено отношение към храмовия патрон на цьрквата (Popov, 1985, р. 23), (Robov, 1985, р. 402). Възможно е храмов патрон на цьрква №3 sа е била св. Богородица и като възможен прочит на откривани тук полглазурни монограми върху стените на сьлове, изработени в сграфрито техника, в контекста на това столично явление, което се появява в Търново около средата на XIV век и изчезва в края на това толетие, очевилно с палането на Търново и залеза на Второто царство. Върху Аве съсеАни тераси,запално и югозапално от цьрква №3 е офрормен планово голям затворен ансамбъл.

Портата на комп^екса, ситуирана в югозапалната му част е одрормена като представително съорьжение. Кьм нея отвежда пьт, свързвал терасата с основната артерия на Трапезица, межлу северната и югоизточната й порти. В рамките на комп^екса, пьтят слеАва непосредствено трасето на южния огрален зил на двора. Алеята свързва ансамбъла с основната комуникационна артерия на Трапезица улицата межлу северната и южната порти на крепостта. Портата е с Аьлжина от почти 5 м и светьл отвор на прохола 3,50 м. Наст^ана е с каменни плочи, като настилката продьлжава и източно от съорьжението.

Проходьт е със сводово покритие, носено от тухлен арков пояс, като петите на арката са стьпвали вьрху пиластри откьм вътрешните ^ица на Авата зила. Ширината на тухлените релове и тази на хоросановата фуга е изравнена, с похват, който познаваме от офрормлението на някои от търновските цьркви, например (Robov, 1996, р. 250). Многобройни фррагменти от стенопис свилетелстват за вьтрешната украса на портата. Освен прецизната зидария от грижливо обработени камъни, положени в правилни редове, в общата фасална Аекорация са включени и 
многобройни керамопластични елементи. Това са кръгли панички, покрити със зелена глазура.

Каменна настилка, източно от портата, отвежАа към постройка с внушителни размери, елинствена в плана на затворения ансамбъл. Кьм тази сграда отвежАа и каменната настилка от запалната странична галерия на цьрквата, ориентирана в посока югозапал, като очертава вътрешна за комплекса алея (Robov, Dochev, 2008, р. 686).

Сградата е Авуделна, с обща Аьлжина от 32 м по оста изток-запал.

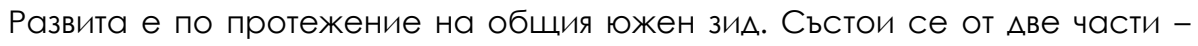
запалната със стопанска функция, а източната предназначена за обетателя на комплекса.

Сграла „А" е офрормена като навес, затворен с П-образен гралеж. Северната му фасала, с $ь$ ьжина от 8,80 м, остава отворена. Целта е Аиректна комуникация с портата. Нахолките в запалната сграла, като полкови, сбруя, апликации, конски зъби показват, че в приземиено е била разположена конушнята на комплекса. Вътрешно стьлбище, върху трапецовиАна основа е отвежАало към горно ниво, пригодено найвероятно за ск^аА. За това свиАетелстват и откритите тук оловни п^омби, прикрепени към съхраняваните товари. Аебелината на зиловете показва, че източната сграла, свързана с обетателя, е била поне Авуетажна. Вътрешно членение, както и останки от подова настилка, не се установяват. Северният зил на постройката е елноредов, като очевилно е играл роля на стилобат за Аървена колонала върху която е стьпвал чарлак. Приземието, на нивото на вътрешния Авор на комплекса, е било одрормено като полчарАачно пространство.

Комплексьт е ситуиран е върху две съселни тераси. На по-високата от тях, северната, е изгралена цьрква №3. Функционална врьзка към обширната тераса, северно от комплекса, не е установена. Следователно, установения огрален за двора зил от север е всъщност и северна граница на комплекса.

В общия силует на архитектурния ансамбъл, а и на този участьк от крепостта Трапезица, цьрква №3 е въздействала като архитектурна Аоминанта. Чрез плочникова настилка, тя е свързана с еАинствената сграла в комплекса, ситуирана в югоизточната му част. Също с плочникова 
настилка, сградата е свързана с еАинствения установен поАхоА Към вътрешността на комп^екса, през портата, в югозапаАната част от п^ана.

Като цяло, очертания архитектурен ансамбъл е включен в огралено Аворно пространство, като естествената Аоминанта е самата цьрква. Тя е ситуирана на по-високата, северна тераса. Според установените при проучването Аанни, просъществувал е $А$ края на 14 век.

П^ановата и функционална характеристика на комплекса го определя като граждански, сходен с болярското жилище, северно от Авореца на Царевец. Той носи в плановите си особености елементи от тралицията в устройството на някои от гражАанските комплекси в столиците на Пьрвото царство (Popkonstantinov, 1980), (Totev, 1995, p. 321 ).

Наличието на зилани гробни съоръжения в притвора на цьрква №3 е свилетелство за високия статус на обетателите тук, собствено като представители на висшата столична аристокрация. Офрормен така, комплексът няма аналог в общата градоустройствена картина на Трапезица /на сегашния етап от проучванията/ и силно се Аоближава като устройство и орункция Ао т.нар. Болярски комплекс на Царевец (Nikolova, 1973). Той е изАигнат на площала, северно от Авореца.

Паралельт с Болярския комплекс на Царевец, като плановокомпозиционно решение на елин затворен архитектурен комплекс в чертите на столичното укрепено пространство, Аава основание комплексът при цьрква №3 да бъле определен като представителен ансамбъл, обетаван от висши представители на столичната, а вероятно и на предстоличната аристокрация, както показва и богатият нумизматичен материал, илюстриращ обетаване през целия този периол. Откритият тук костен завършек на архиерейски жезъл, Аава определено основание комплексът $\Delta а$ се свърже с висш представител на столичното Ауховенство, най-вероятно с епископски сан (Robov, 2019a).

Изборьт на това престижно място за изграждането на затворен комп^екс е удачен от всяка гледна точка. Терасата среА най-високите, които предлага билото на Трапезица. Тя е сльнчева и хигиенична, с великолепен изглеА, вкАючително и към преАставителните институции на Царевец - Авореца и патриаршията. Цьрква №3 е ситуирана в най- 
Източната част на ограленото пространство, а това запазва целостта на Аворното пространство.

Широка, около 3 м алея, е осигурявала на комплекса непосредствен излаз към трасето на основната комуникация в крепостта Трапезица, улицата межАу северната и южната порти.

Цьрква №4. Разположента е непосредственои Южно от цьрква №3, но на по-ниска тераса. Разкрита е по време на втората археологическа кампания, т.е. при разкопките от 1884 гол., поА ръково Аството на А-р Васи^ Берон. По план постройката е елнокорабна, кръстокуполна, от типа „стегнат крьст". От изток завьршва с тристенна апсила. ЕАин притвор. Гралена със смесен градеж. Наосът е с поти квалрани пропорции. Източното и запалното крьстни рамена са много къси. Фасалите са пластично разчленени на Авустьпални Аекоративни ниши, аркирани и несьмнено с богата керамопластична Аекорация 17, като при повечето цьркви на хъ^ма.

Цьрква №14. Разкрита при разкопките на Жорж Сьор през 1900 г. Като повечето цьркви на Трапезица е еАнокорабна, с полуцилинАричен своА. Различното при нея е Аобавянето на втори притвор, като етап в равитието на плана. СпореА Васил Аимов, цьрквата е причислена към т.нар. "царски цьркви" на Трапезица зарали наличието на царски персонажи във вътрешната стенописна украса. Това са три царски изображения, Аве жени и един мъж, с къса пурпурна мантия, украса от бисери и скъпоценни камьни.

Цьрквата попала в групата на цьркви-гробници, с Аолен гробничен етаж в южната половина на притвора. Пьрвоначалната запална фрасала

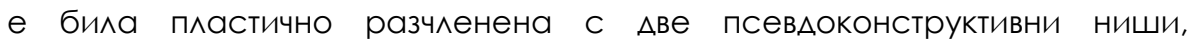
разположени от Авете трани на входа. Три ниши е имало от изток и по пет

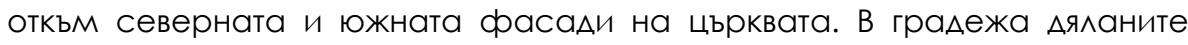
камъни се редували с тухлени пояси. Фасалите са били богато декорирани с керамоп^астична украса, многобройни фрагменти от която се откриват в насипите покрай южната крепостна стена.

Вьрху третата към юг тераса в югоизточния сектор на Трапезица,през 40-те голини на 13 век е изАигната голяма Авуделна преАставителна постройка, непосредствено върху участька на фрункционсиралият от края 
на 12-ти Ао 30-те години на 13 век голям железарски комплекс.ВиАно от откритите тук монети е просъществувала Ао края на век.

Западната постройка е с правоъгълен план и с внушителни размери. Ширината й напьлно обхваща ширината на самата тераса. В средата на Непосредствено пред запалната фрасала е офрормено хо Аово ниво С каменна настилка, която отвежАа към стьпала, свьрзващи сградата с улицата от юг. Това показва, че вьпросната постройка функционално не е била свързана с разположената непосрелствено от север епископия, а е фрункционсирала като като самостоятелен архитектурен обем. Вътрешното членение /ако е имало такова/ очевинно е било реализирано с масивна Аьрвена конструкция. Подовата настилка е от каменни п^очи положени вьрху трамбованата прьст.

Откритата масивна варовикова колона, както и Аве каменни бази са важен щрих в представителното офрормление на вьпросната постройка. ВиАно от мястото, къАето са открити, те най-вероятно са били положени вьрху нейния източен зиА, част от който е граден на хоросанова спойка и е грижливо измазан откъм източната си страна. Относно фрункционалното преАназначение на вьпросната Авуделна постройка от определящо значение е нейната източна половина офрормлението на нейната източна половина. Със строителна техника, като установената тук, са гралени и офрормени най-представителните сграли на Трапезица. Налице са податки за сложен план на сградата, както и за контруктивните решения в интериора. От изток е установена и част от Аьговилен градеж, чиято пьлна реконструкция затваря апсила. Найвероятно става въпрос за новооткрита постройка с култово предназначение. Аипсата на стенопис, обаче, показва че това не е християнски храм.

От Аруга страна, Аолепената от запал голяма правоьгьнна постройка, по-скоро Аопьлва фуунцциналната й характеристика като култово-обществена сграАа. Напьлно възможно е в случая, Авуделната

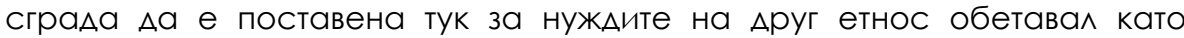
^окализирана тук колония именно частк от крепостта Трапезица. Такива Аанни, ако се Аоверим на запазената топонимия, съществуват елинствено по отношение на евреите като част от населението на столично Търново (Chaneva-Dechevska, 1988, p. 121), (Robov, 2019b). В 
полкрепа на това са определени нахолКи, открити в пластовете на проучваната Авуделна постройка.

СреА тях е Аьно от сьА, украсен в сграфито техника и изобразена като централна композиция звезАа на АавиА. На Аосегашния етап от разкопките в сектор Югоизточен се очертава интересна градоустройствена картина, различна от това, което се установява в Аругите Ава проучвани сектора - Южен и Северен. Тук жилищен квартал не се установява и не се очертава. В проучвания участьк структурообразуваща е ролята на големия затворен фреолален ансамбъ^ при цьрква №3. Той е разгърнат като планово решение върху Аве съселни тераси. Вьрху по-високата от тях е цьрква №3 с роля на архитектурна доминанта в тази част от градската среда. Върху втората, по-ниска тераса е поставена портата кьм комплекса с широка алея, която свързва ансамбъла с централната алея на крепостта по оста север-юг. Върху тази тераса, непосредствено източно от портата е ситуирана голяма Авуделна сграда, непосредствено свързана с обетателя на комплекса - високопоставено цьрковно ^ице, виАно и от намерения костен завьршек на архиерейски жезьл. В предшестващ периол/края на XII-30-те голини на XIII век, тук са били разположени производствените съоръжения на голям комплекс за обработка на желязо/. Върху най-южната от трите тераси е разположена голяма Авуделна постройка с внушителни размери: изток-запал - около 21 м; север-юг - 13,50 м /външни размери/. От изток завършва с апсида. Източната й част е гралена на хоросанова спойка, грижливо измазана с хоросан отвътре. Самата постройка вероятно е с обществена или религиозна функция, като на този етап от разкопките тя категорично не може $а$ а се приеме като енна от цьрквите на Трапезица - планово, а и с особеностите на вьтрешното си оформление. 


\section{Образи, ползвани в текста:}

Обр.1. Църквите в

юго-източния сектор

на Трапе-зица.

Манасиева хроника.

Миниатюра върху .2

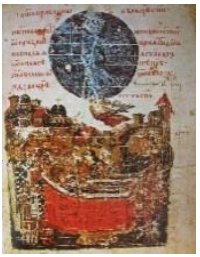

Обр.4. Авуделна култова постройка.

Апси $а$ a

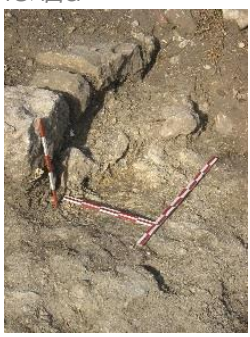

Обр.2. Епископия. Порта

Обр.3.

Епископия. Възстановка
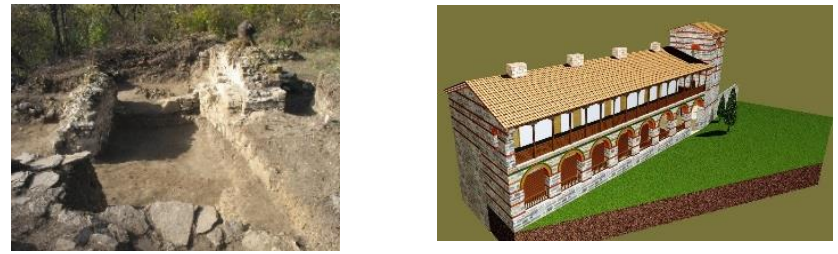

Обр.5.

ЗвезАата на АавиА върху сграфрито съА.

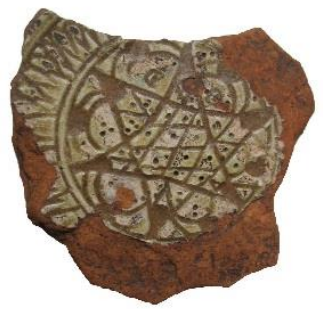

\section{AИTEPATYPA / REFERENCES}

Beron, V. (2004). Arheologicheski i istoricheki izsledvaniya. Veliko Tarnovo, 2004 // [Берон, В. (2004)Археологически и историчеки изследвания. Велико Търново, 2004 г., с. 18]

Chaneva-Dechevska, N. (1988). Tsarkovnata arhitetura v Balgariya prez XI-XIV vek. Sofia // [ЧаневаАечевска, Н. (1988) Цьрковната архитетура в Бьлгария през XI-XIV век. С., С.121]

Dimov, V. (1915). Razkopkite na Trapezitsa v Tarnovo. IBAD, volume. V, 1915, s.129-130 // [Аимов, B. (1915) Разкопките на Трапезица в Търново. ИБАА, т.V, 1915, с.129 и с^.]

Domuschiev, N. (1967). Za datata na osnovavaneto na parvoto arheologichesko druzhestvo $\vee$ Balgariya. Arheologiya, IX, 1967, book 2 // [Аомусчиев, Н. (1967) За Аатата на основаването на пьрвото археологическо Аружество в България. Археология, IX, 1967, кн.2, с.61]

Duychev, I. (1962). Miniatyurite na Manasievata letopis. S., 1962 // [Ауйчев, И. (1962) Миниатюрите на Манасиевата летопис. С., 1962, с.32]

Mavrodinov, N. (1931). Ednokorabnata i krastovidnata tsarkva po balgarskite zemi do kraya na XIV v. Sofia, 1931 // [Мавродинов, Н. (1931) ЕАнокорабната и крьстовидната цьрква по българските земи Ао края на XIV в. С., 1931, с.36]

Mavrodinov, N. (n.d.). Posledni Sachinenia.// [Мавродинов, Н. Пос. Съч., с.36] 
Nikolova, Ya. (1962). Nyakolko dokumenta za razkopkite $v$ Tarnovo i Nikopolis ad Istrum prez $1900 \mathrm{~g}$. IOMT, kn.l, Varna, 1962 // [Николова, Я. (1962) Няколко Аокумента за разкопките в Търново и Никополис аА Иструм през 1900 г. ИОМТ, кн.1, Варна, 1962, с.35]

Nikolova, Ya. (1973). Zhilishtnata arhitektura v Tarnovo prez XII -XIV vek. TrVTU „Kiril i Metodiy”, volume VIII, book 2, IF, 1970-1971, Sofia, 1973, s.111-121 // [Николова, Я. (1973)Жилищната архитектура в Търново през XII-XIV век. ТрВТУ „Кири^ и Методий”, т.VIII, кН.2, ИФ, 1970-1971, С., 1973, с.111121]

Popkonstantinov, K. (1980). Grazhdanski kompleksi v Pliska i Preslav. Srednovekovniyat balgarski grad. Sofia, 1980, s.117-118 // [Попконстантинов, К. (1980) ГражАански комплекси в Плиска и Преслав. Средновековният български граА. С., 1980, с.117-118]

Popov, A. (1985). Ivan-Aseneviyat manastir „Velikata lavra" $\vee$ Tarnov. Kulturata na srednovekovniya Tarnov, Sofia, 1985 // [Попов, А. (1985) Иван-Асеневият манастир „Великата ^авра" в Тьрнов. Културата на средновековния Търнов, С., 1985, с.23]

Robov, M. (1985). Za upotrebata na sadove s tsarski i patriarsheski monogrami prez XIII-XIV vek. Tarnovska knizhovna shkola, volume IV, Sofia,1985 // [M. Робов. За употребата на сьдове с царски и патриаршески монограми през XIII-XIV век. Търновска книжовна школа, т.IV, C., 1985, c.402]

Robov, M. (1996). Nablyudeniya varhu keramoplastichnata ukrasa po tarnovskite tsarkvi /XII -XIV v./. Bog i tsar $v$ balgarskata istoriya, Plovdiv, 1996 // [Робов, М. НаблюАения вьрху керамопластичната украса по тьрновските цьркви /XII-XIV в./. Бог и цар в българската история, ПАОвАив, 1996, с.250]

Robov. M. (1999). Podglazuren monogram na Teodosiy Tarnovski ot Kilifarevskiya manastir. Tarnovska knizhovna shkola, volume VI, Veliko Tarnovo, 1999 // [М. Робов. (1999) Подглазурен монограм на Теодосий Търновски от Килифраревския манастир. Търновска книжовна школа, т.VI, Велико Търново, 1999, с.521]

Robov, M. (2002a). Bog i tsar $\vee$ balgarskata istoriya. Plovdiv, 1996 // [Робов, М. (2002) Бог и цар в българската история. ПАовАив, 1996, с.251]

Robov, M. (2002b). Risuvanata fasadna ukrasa na tsarkvata "Sv. Dimitar" vav Veliko Tarnovo. Tarnovska knizhovna shkola, volume 7, Veliko Tarnovo, 2002, pp. 766-768 // [Робов, М. Рисуваната фрасална украса на цьрквата „Св. Аимитьр" във Велико Търново. Тьрновска книжовна школа, т.7, Велико Търново, 2002, с.766-768]

Robov, M. (2019a). Kosten arhiereyski zhezal of zatvoreniya kompleks pri tsarkva №3 na Trapezitsa. Tarnovska knizhovna shkola, 11, Veliko Tarnovo, ISBN 978-619-208-181-2, pp. 407-416 // [Робов, М. (2019) Костен архиерейски жезь^ от затворения комп^екс при цьрква №3 на Трапезица. Търновска книжовна школа, 11, Велико Търново, ISBN 978-619-208-181-2, с.407-416]

Robov, M. (2019b). Za padaneto na Tarnovo prez yuli 1393. Tsamblakovi cheteniya, Veliko Tarnovo, ISBN 978-619-208-195-9, рр. 254-255 // [Робов, М. (2019) За палането на Търново през юли 1393 г. Цамблакови четения, Велико Търново, ISBN 978-619-208-195-9, с.254-255]

Robov, M., Dochev, K. (2008). Arheologicheski razkopki na Trapezitsa, sektor „Yugoiztochen” /tsarkva №3/. AOR prez 2007, Sofia, 2008 // [Робов, М., Аочев, К. (2008) Археологически разкопки на Трапезица, сектор „Югоизточен” /цьрква №3/. АОР през 2007 г., С., 2008, с. 689 и обр.1 на c.686]

Totev, T. (1995). Novi nablyudeniya i danni za oblika na grazhdanskata arhitektura prez Parvoto balgarsko tsarstvo. Preslavska knizhovna shkola, volume 1, Shumen, 1995 // [Тотев, Т. Нови наблюдения и данни за облика на гражланската архитектура през Пьрвото бьлгарско царство. Преславска книжовна школа, т.1, Шумен, 1995, с.321] 


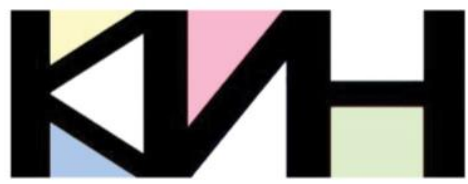

КУАТУРНО-ИСТОРИЧЕСКО НАСАЕАСТВО:

ОПАЗВАНЕ, ПРЕАСТАВЯНЕ, АИГИТААИЗАЦИЯ

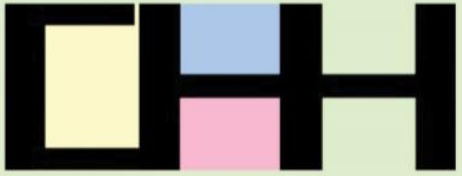

CULTURAL AND HISTORICAL HERITAGE: PRESERVATION, PRESENTATION, DIGITIZATION
Материалите в сборника са обект на авторско право. Разрешава се безвъзмезАното ползване на техни електронни/ хартиени копия само за лична употреба или обучение, при пь^но цитиране на текущата страница и слеА писмена декларация от цитиращия за мипса на търговски намерения.

(с) Авторски колектив, 2020

Техническо реАактори: Калина Сотирова-Вълкова Николай Ноев Паска^ Пиперков

\section{Editors}

Petko St. Petkov

Galina Bogdanova

This work is subject to copyright. Open and free of charge use of digital/hard copies of publications is granted only for personal or educational use, with full citation of the current page, and after written declaration of the quoting side for notcommercial Intention.

(C) Authors` Group, 2020

Technical editors:

Kalina Sotirova-Valkova

Nikolay Noev

Paskal Piperkov

НАЦИА регистрационен № 1209

Научна пореАица: том 6, брой 2 (9)/2020

Science series: vol. 6 , issue $2(9) / 2020$

NCID Registry No. 1209

www.math.bas.bg/vt/kin

ISSN: 2367-8038 